\title{
Japan tackles downturn in science funding
}

Tokyo. Japan's science and technology has reached a turning-point, according to the latest annual 'white paper' on research released this week by the Science and Technology Agency (STA).

As a result of the country's prolonged recession, investment in research and development has begun to decline for the first time since the $1950 \mathrm{~s}$, while young people are showing less interest in science and technology.

After decades of almost exponential growth, for example, the document shows how Japan's expenditures on research fell for the first time in the fiscal year 1993, which ended in March 1994, due to reduced expenditure by the private sector.

A slight upturn in government expenditure as a result of numerous supplementary budgets was insufficient to offset the decline in spending, which has brought expenditure down from a peak of 2.78 per cent of gross national product (GNP) in 1990 to 2.66 per cent in 1993.

Adding to the gloomy picture is clear evidence that Japan's youth is showing less interest in science. Individuals in their forties and fifties have shown a steady increase in interest in science and technology over the past decade. In contrast, those in their twenties have shown a rapid decline in interest; now only just over 40 per cent

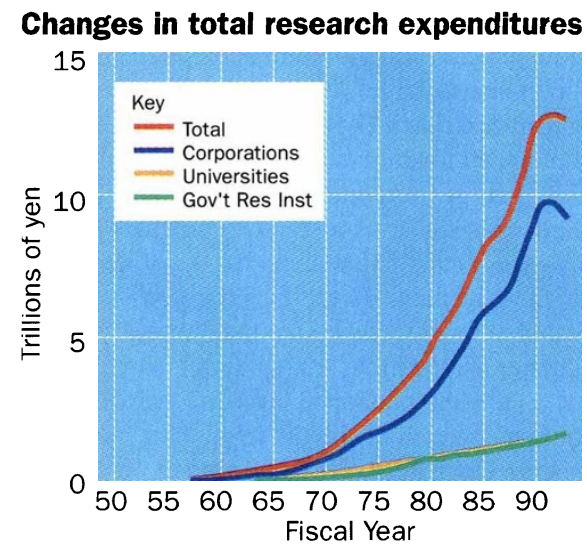

say they are "very interested" or "somewhat interested" in news topics related to science and technology.

On top of this decline, the Kobe earthquake in January and the nerve gas attacks in Tokyo and Matsumoto have helped to undermine still further the faith of Japan's public in science and technology.

To overcome this situation, the STA document says that Japan must take steps to become a nation based on what it calls "creative" science and technology. Such exhortations have been repeatedly made in white papers over the past decade. But for the first time the agency lists some specific measures to revitalize Japan's government research and development.

For example, the paper calls for more flexible employment of researchers to encourage mobility between institutions by, for example, offering higher pay to talented researchers and greater security for those on short-term contracts. Such suggestions may seem obvious to western researchers but are quite radical for Japan.

In line with these proposals, the agency echoes a popular government theme over the past few years by calling for the creation of centres of excellence that can attract talented researchers from Japan and other parts of the world.

It also calls for increased use of external evaluation of research institutes to assess the quality of research and administration. Since 1993, a handful of government institutes and university institutes - led by STA's Institute of Physical and Chemical Research (RIKEN) and Tokyo University's physics department - have brought in teams of external reviewers from Japan and overseas (see Nature 365, 97; 1995).

The 'white paper' says more research institutes should make use of such reviews. It also urges greater government investment in research and development. But given the poor state of Japan's economy, a dramatic change in this seems unlikely.

David Swinbanks

\section{Vote on growth hormones in meat sparks row with FAO}

London. The European Commission is deadlocked with the United Nation's main food agency over whether scientific evidence is sufficient to lift a ban on the importation and use of meat enhanced with growthpromoting hormones.

Earlier this month, the UN Food and Agriculture Organization (FAO), after a wide-ranging review, concluded that the European Union (EU) ban, which has been in force since 1989, lacked any scientific basis. It voted at a closed secret meeting on 6 July to approve the use of growth hormones in meat for domestic consumption as well as export among its member states.

But the European Commission - the body charged with overseeing EU legislation - remains unrepentant. Franz Fischler, the EU's agriculture commissioner, denounced the decision as unrepresentative, and confirmed that the ban on imports of hormoneenhanced meat would remain.

"The decision, which essentially was only supported by 20 per cent of the signatories of GATT, will have no bearing on the EU's policy on hormones," he says. The decision was adopted by 33 votes in favour, to 29 against, a majority of four, with seven abstentions and 25 spoiled ballot papers. Ninety-four nations out of 151 member states were represented at the meeting. "If we are to adapt our policy, we will do so using our own decision-making process."

The decision was taken by the Codex Alimentarius Commission, a joint FAO/ World Health Organization (WHO) body responsible for international food standards. The commission authorized the use in meat of three naturally occurring hormones, namely testosterone, progesterone and oestradiol, as well as two synthetic hormones, zeranol and trenbolone.

Growth-inducing hormones are used to produce leaner, more muscular meat. Hormones are administered before an animal goes to slaughter, and the maximum residue limits (MRL) are set below a concentration that induces hormonal effects in the animal.

The three naturally occurring hormones are not subject to safety levels as they are already present in the animal's body. Fritz Käferstein, head of food safety at WHO, says there is "no appreciable risk to humans" from consuming hormone-enhanced meat.

The Codex commission is not the only body opposed to the EU ban, as opposition also exists within the EU member states. The British government - which has consistently opposed the ban since its enforcement — issued a statement after the FAO vote saying that it would take up the cause again when the European Commission holds a conference this autumn reviewing its approach to hormone use.

"The UK opposed the introduction of the initial ban on the use of hormonal growth promoters, on the grounds that the ban was not scientifically justified, and this remains the case," according to the statement issued by the Ministry of Agriculture, Fisheries and Food. "The UK welcomes the conference proposed by the commission to review the situation," the statement added. "But any decisions made as a result should be firmly based on science."

A ministry spokesman later explained that Britain felt that the EU ban was grounded in concern over competitiveness rather than scientific reasons. It was in force, he said, primarily to protect Europe's small meat-producers who, unable to afford hormone-enhancement facilities, might be wiped out by larger manufacturers from the United States if the ban was lifted.

Hormone-enhanced imports of US beef to the EU have been banned since 1989. The US government, which welcomed the Codex decision, had threatened to take the issue to the World Trade Organization if the ban is not revoked.

Ehsan Masood 